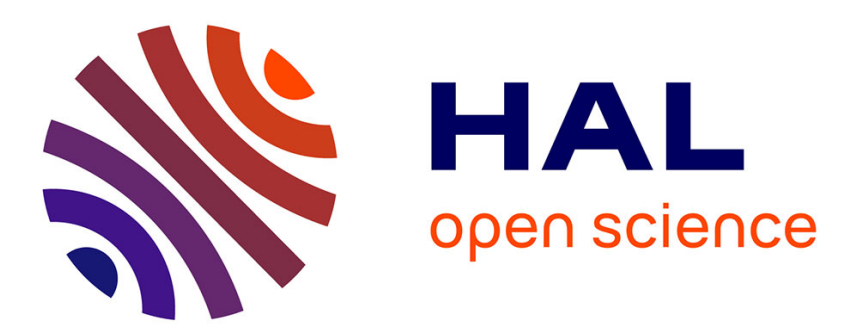

\title{
ENSO and Short-Term Variability of the South Equatorial Current Entering the Coral Sea
}

\author{
W. S. Kessler, S. Cravatte
}

\section{To cite this version:}

W. S. Kessler, S. Cravatte. ENSO and Short-Term Variability of the South Equatorial Current Entering the Coral Sea. Journal of Physical Oceanography, 2013, 43 (5), pp.956-969. 10.1175/jpo-d12-0113.1 . hal-00996350

\section{HAL Id: hal-00996350 https://hal.science/hal-00996350}

Submitted on 26 May 2014

HAL is a multi-disciplinary open access archive for the deposit and dissemination of scientific research documents, whether they are published or not. The documents may come from teaching and research institutions in France or abroad, or from public or private research centers.
L'archive ouverte pluridisciplinaire HAL, est destinée au dépôt et à la diffusion de documents scientifiques de niveau recherche, publiés ou non, émanant des établissements d'enseignement et de recherche français ou étrangers, des laboratoires publics ou privés. 


\title{
ENSO and Short-Term Variability of the South Equatorial Current Entering the Coral Sea
}

\author{
WILLIAM S. KESSLER \\ NOAA/Pacific Marine Environmental Laboratory, Seattle, Washington \\ SOPHIE CRAVATTE \\ Institut de Recherche pour le Développement, Nouméa, New Caledonia
}

(Manuscript received 23 June 2012, in final form 20 December 2012)

\begin{abstract}
Historical section data extending to 1985 are used to estimate the interannual variability of transport entering the Coral Sea between New Caledonia and the Solomon Islands. Typical magnitudes of this variability are $\pm 5-8 \mathrm{~Sv}\left(\mathrm{~Sv} \equiv 10^{6} \mathrm{~m}^{3} \mathrm{~s}^{-1}\right)$ in the 0-400-m layer relative to $400 \mathrm{~m}$, and $\pm 8-12 \mathrm{~Sv}$ in the 0-2000-m layer relative to $2000 \mathrm{~m}$, on a mean of close to $-30 \mathrm{~Sv}$ (relative to $2000 \mathrm{~m}$ ). Transport increases a few months after an El Niño event and decreases following a La Niña. Interannual transport variability is well simulated by a reduced-gravity long Rossby wave model. Vigorous westward-propagating mesoscale eddies can yield substantial aliasing on individual ship or glider surveys. Since transport variability is surface intensified and well correlated with satellite-derived surface geostrophic currents, a simple index of South Equatorial Current transport based on satellite altimetry is developed.
\end{abstract}

\section{Introduction}

The South Equatorial Current (SEC) is the westward limb of the South Pacific subtropical gyre, carrying the gyre's accumulated dynamical and water property influences to the western boundary where they are redistributed equatorward or poleward. Three primary branches are produced as the current splits around the two large island chains of the western Pacific (New Caledonia and the Solomon Islands, Fig. 1), each of which includes extensive reef systems that block flow over at least $5^{\circ}$ of latitude. None of the three branches has been fully described. The northern branch is thought to turn equatorward east of the Solomon Island chain, bypassing the Coral Sea (e.g., Johnson and McPhaden 1999; Zilberman et al. 2013). The southern branch is found south of New Caledonia and turns southward at the coast of Australia into the East Australian Current (Ridgway and Godfrey 1994). The present paper is concerned with the middle branch, flowing into the Coral Sea through the $800-\mathrm{km}$-wide gap between the

Corresponding author address: William S. Kessler, NOAA/ PMEL, 7600 Sand Point Way NE, Seattle, WA 98115.

E-mail: william.s.kessler@noaa.gov tip of the New Caledonian reef and the southernmost of the Solomon Islands. This branch has been further divided as it passes Fiji and Vanuatu (Fig. 1), entering the Coral Sea in two zonal jets with distinct characteristics (Gourdeau et al. 2008): the North Caledonian Jet and the North Vanuatu Jet (Fig. 2c). These jets cross the Coral Sea and bifurcate at the Australian coast (Qu and Lindstrom 2002; Ganachaud et al. 2008) turning partly south into the Tasman Sea (Ridgway and Dunn 2003) and partly north into the Solomon Sea (New Guinea Coastal Undercurrent, Gasparin et al. 2012; Davis et al. 2012), eventually reaching the equator (Tsuchiya et al. 1989; Fine et al. 1994; Grenier et al. 2011).

It has been long known, and is expected from simple dynamical ideas (Holbrook and Bindoff 1997, 1999), that transport of the middle branch of the SEC varies annually (Kessler and Gourdeau 2007) and with the ENSO cycle (Delcroix and Henin 1989; Holbrook and Bindoff 1997; Alory and Delcroix 2002; Gouriou and Delcroix 2002). These represent changes in the transport of warm and salty subtropical waters advected into the Coral Sea and then poleward or equatorward as the current bifurcates. Downstream, this will potentially modify the water properties of the Tasman and Solomon Seas, and 

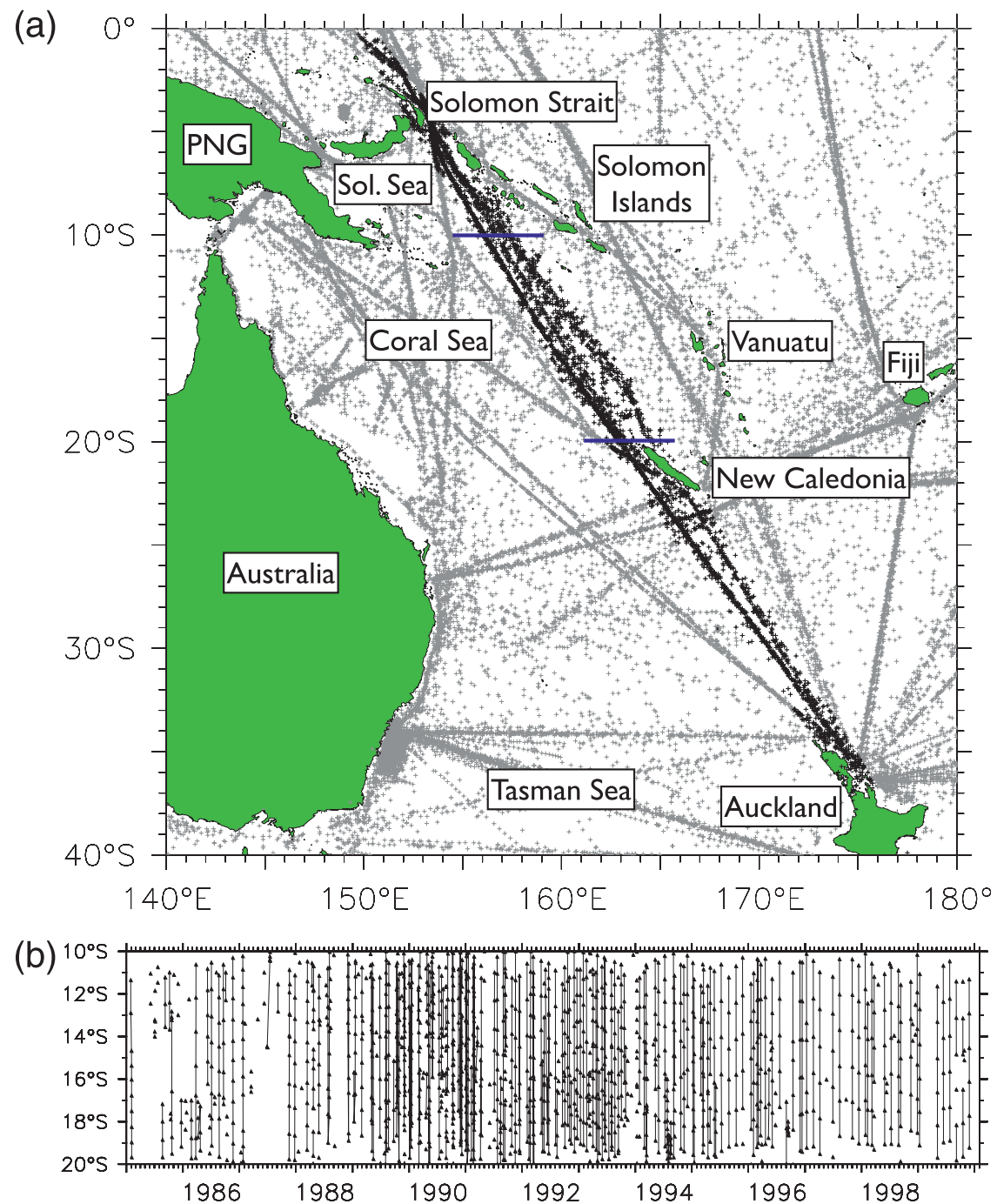

FIG. 1. (a) XBT profiles in the southwest Pacific, showing the selected track from Auckland to Solomon Strait: 3917 profiles were selected (dark crosses) of which 1346 were in the $20^{\circ}-10^{\circ} \mathrm{S}$ region considered here (blue lines). Locations mentioned in the text are labeled as Papua New Guinea (PNG) and Solomon Sea (Sol Sea). (b) IFREMER XBT profiles in the southwest Pacific, showing the time history of profiles on the selected track in Fig. 1a. Profiles that could be grouped by voyage are connected by a line. About $15 \%$ of profiles could not and are shown as isolated dots.

consequently of the equatorial western Pacific (Fine et al. 1994).

Developing time series of this transport variability has been difficult because much of the historical data consists of occasional ship surveys that are hard to put in context. With the advent of the Argo program (Roemmich and Gilson 2009), this problem will be largely rectified for the future, but Argo sampling of the Coral Sea became sufficiently dense only in 2005 or 2006 . The purpose of this paper is to make use of older data to extend the transport time series back before the Argo era. We would also like to develop indices that could allow satellite altimetry (which goes back to 1992) to be used as a proxy for interannual transport variations; the temporally uniform satellite sampling also gives the opportunity to evaluate high-frequency signals that could alias ship surveys or Argo diagnoses.

Several estimates of transport entering the Coral Sea based on ship surveys have been published, but these vary by almost a factor of 2 (Wyrtki 1962; Scully-Power 1973; Andrews and Clegg 1989; Sokolov and Rintoul 2000; Gourdeau et al. 2008; Gasparin et al. 2012) (see 


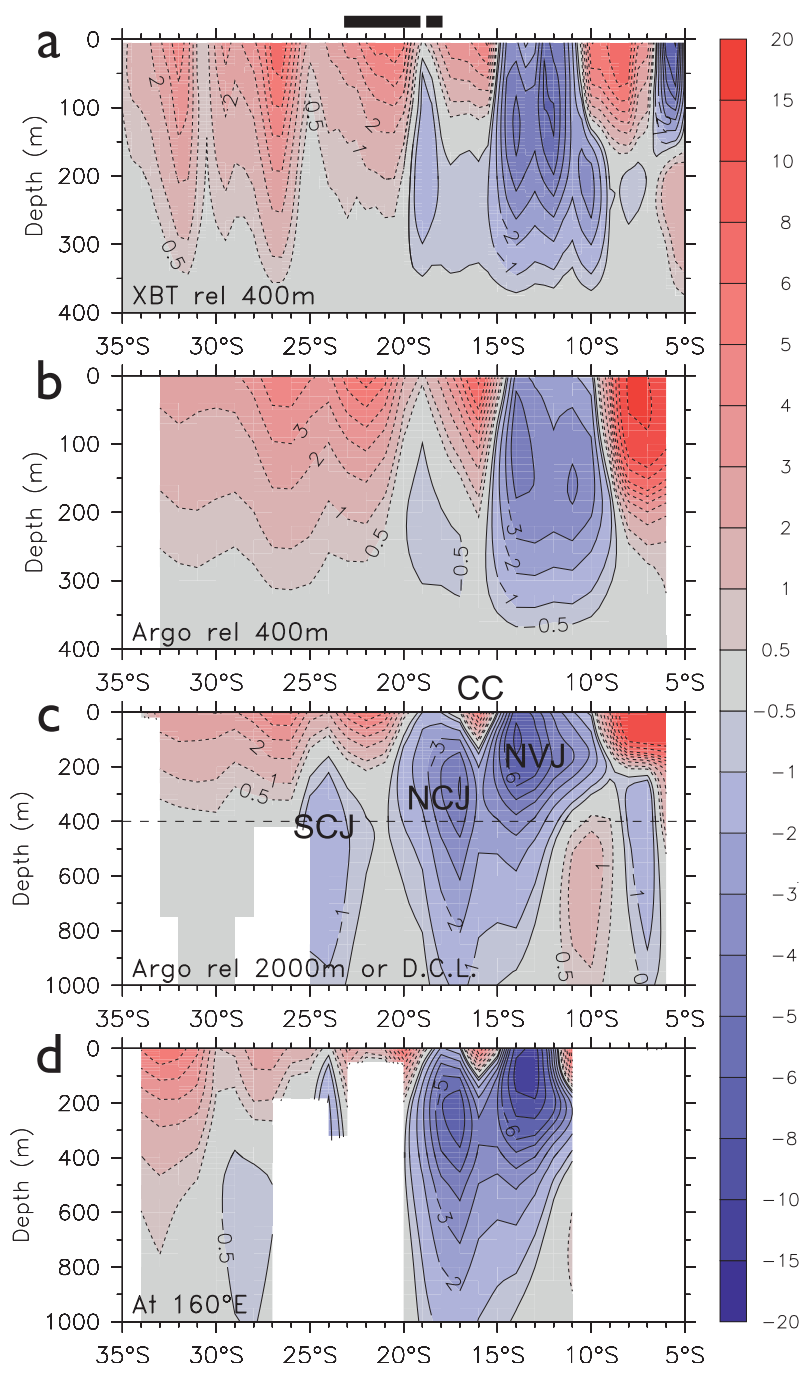

FIG. 2. Mean cross-track geostrophic speed $\left(\mathrm{cm} \mathrm{s}^{-1}\right)$ on the XBT track: negative values (blue) cross the track to the west. (a) XBT relative to $400 \mathrm{~m}$, (b) Argo relative to $400 \mathrm{db}$, (c) Argo relative to $2000 \mathrm{db}$, and (d) Argo meridional section at $160^{\circ} \mathrm{E}$, relative to $2000 \mathrm{db}$. The three westward jets named in the text are identified in (c) as the South Caledonian Jet (SCJ), North Caledonian Jet (NCJ), and North Vanuatu Jet (NVJ) along with the shallow eastward Coral Sea Countercurrent (CC). The thick black bars at top between $23^{\circ}$ and $18^{\circ} \mathrm{S}$ show the latitude of New Caledonia and its reef (just east of the XBT track), broken by the Grand Passage near $19^{\circ} \mathrm{S}$

Table 1), confusing the interpretation of these data. There are several factors that cause such estimates to differ: sampling locations (especially obtaining adequate resolution of the narrow zonal jets and boundary currents), sampling depths, choices of reference level, timing relative to the seasonal or ENSO cycles, and short-term eddy aliasing. By extending the existing time series back before Argo and making use of weekly satellite altimetry, we hope to evaluate these estimates.

\section{Data and methods}

\section{a. An XBT track across the entrance to the Coral Sea}

This study takes advantage of XBTs deployed on a regularly repeated merchant ship track crossing the eastern Coral Sea from Auckland, New Zealand, to Solomon Strait during 1985-99 (Fig. 1). This line was part of the pioneering Scripps Institution of Oceanography/Office de la Recherche Scientifique et Technique Outre-Mer (SIO/ ORSTOM) Volunteer Observing Ship (VOS) XBT program (Meyers and Donguy 1980), with transects made approximately every other month, on average. Crosstrack (approximately southwestward) geostrophic currents were computed as described below.

This ship track does not provide a perfect measure of the middle branch of the SEC entering the Coral Sea between New Caledonia and the Solomon Islands because it does not complete a coast-to-coast section (Fig. 1). The choice of the southern endpoint was straightforward, as the XBT line is very close to New Caledonia and little, if any, flow will be missed (Maes et al. 2007; Gourdeau et al. 2008). We chose the southern endpoint at $20^{\circ} \mathrm{S}$ to include transport coming through the 35-km-wide Grand Passage that breaks the northern New Caledonian reef near $18^{\circ} 45^{\prime} \mathrm{S}$ (Fig. 2; Gourdeau et al. 2008). The choice of the northern endpoint is not obvious, as there remains the possibility of unsampled flow between the XBT track and the Solomon Islands where the circulation is complex (Cravatte et al. 2011; Gasparin et al. 2012; Davis et al. 2012). We chose $10^{\circ} \mathrm{S}$ for the northern endpoint but found that the cross-track transport anomaly time series studied here was not sensitive to choices from $11^{\circ}$ to $7^{\circ} \mathrm{S}$.

It is worth noting that transport across this line is an estimate of total flow entering the Coral Sea, including both eastward and westward flow, not of the westward SEC, which can have ambiguous boundaries that are in addition highly dependent on the choice of reference level [Taft and Kessler (1991), and see the discussion of Fig. 2 below]. Since these flows are also often filamentary, containing embedded countercurrents, defining the SEC specifically appears to be of dubious value, and we focus here on the variability of flow entering the Coral Sea. For convenience we will, however, refer to this as the "SEC."

\section{b. XBT and other datasets}

A total of 3917 XBT temperature profiles, usually to at least $400 \mathrm{~m}$, were made on the Auckland-Solomon Strait track and quality controlled by the Coriolis Data Centre; only profiles with quality flags indicating good data were considered. Of these profiles, 1459 were complete to $400 \mathrm{~m}$ and were within the $20^{\circ}-10^{\circ} \mathrm{S}$ region considered here, an average of about 0.81 profiles per 
TABLE 1. Published values of SEC transport in the Coral Sea: locations labeled "NC-Solomons" denote sections across the entrance comparable to the XBT track studied here.

\begin{tabular}{|c|c|c|c|}
\hline Publication name/year & Location, month/year of section & $\begin{array}{l}\text { Reference } \\
(\mathrm{m} \text { or } \mathrm{db})\end{array}$ & $\begin{array}{l}\text { Transport } \\
\quad(\mathrm{Sv})\end{array}$ \\
\hline \multirow{6}{*}{$\begin{array}{l}\text { Wyrtki (1962) } 6 \text { sections made by ORSTOM researchers } \\
\text { during 1956-60 }\end{array}$} & NC-Solomons, Nov $1956^{\mathrm{a}}$ & 1000 & -23.2 \\
\hline & NC-Solomons, Jun $1958^{\mathrm{a}}$ & 1000 & -25.8 \\
\hline & NC-Solomons, Nov $1958^{\mathrm{a}}$ & 1000 & -5.8 \\
\hline & NC-Solomons, Feb $1960^{\mathrm{a}}$ & 1000 & -24.5 \\
\hline & NC-Solomons, May $1960^{a}$ & 1000 & -12.3 \\
\hline & NC-Solomons, Aug $1960^{\mathrm{a}}$ & 1000 & -14.7 \\
\hline Scully-Power (1973) & $\begin{array}{l}20^{\circ}-12^{\circ} \mathrm{S} \text { along } 157^{\circ} \mathrm{E} \text { (central Coral Sea), } \\
\text { May-Jul } 1968^{\mathrm{b}}\end{array}$ & 1500 & -37 \\
\hline Scully-Power (1973) & NC-Solomons, Aug-Sep $1970^{c}$ & 1500 & -30 \\
\hline Andrews and Clegg (1989) & Vanuatu-Solomons, Oct $1985^{\mathrm{d}}$ & 1000 & -24 \\
\hline \multirow{3}{*}{ Sokolov and Rintoul (2000) } & Along $\sim 154.5^{\circ} \mathrm{E}$ (western Coral Sea), & 2000 & -54 \\
\hline & Jun-Jul $1993^{\mathrm{e}}$ & 1300 & -36 \\
\hline & & 1000 & -30 \\
\hline Gourdeau et al. (2008) (glider geostrophic) & NC-Solomons, Jul-Sep $2005^{\mathrm{f}}$ & 600 & -14 \\
\hline Gourdeau et al. (2008) (absolute above $600 \mathrm{~m}$ ) & NC-Solomons, Jul-Sep 2005 & 600 & -31 \\
\hline Gourdeau et al. (2008) (shipboard geostrophic) & NC-Solomons, Jul-Sep $2005^{\mathrm{h}}$ & 2000 & -28 \\
\hline Gasparin et al. (2012) & NC-Solomons, Aug 2007 ${ }^{i}$ & 2000 & -24 \\
\hline \multirow{7}{*}{$\begin{array}{l}\text { Present paper, all values calculated along the XBT track, } \\
\text { from New Caledonia to the eastern Solomon Sea (Fig. 1) }\end{array}$} & $(\text { XBT mean } 1985-99)^{\mathrm{j}}$ & 400 & -7 \\
\hline & $($ Argo mean 2004-11) & 400 & -6 \\
\hline & $(\text { CARS long term mean })^{\mathrm{j}}$ & 400 & -7 \\
\hline & $(\text { Argo mean } 2004-11)^{\mathrm{j}}$ & 1000 & -22 \\
\hline & (CARS long term mean $)^{\mathrm{j}}$ & 1000 & -24 \\
\hline & $($ Argo mean 2004-11) & 2000 & -27 \\
\hline & $(\text { CARS long term mean })^{\mathrm{j}}$ & 2000 & -30 \\
\hline
\end{tabular}

a Transports calculated from endpoint dynamic height differences and unknown choice of $f$, includes westward flow only.

${ }^{\mathrm{b}}$ Section began and ended in midocean, May-July 1968.

${ }^{\mathrm{c}}$ Meridional section along $162^{\circ} \mathrm{E}$ (ended slightly east of Solomons), Aug-Sep 1970.

${ }^{d}$ Includes Indispensable Strait, transport diagnosed using vertical normal modes (large modification of geostrophic values), Oct 1985.

${ }^{\mathrm{e}}$ WOCE P11S line, transport values include only station pairs with westward transport (S\&R-defined SEC, from about $14.3^{\circ} \mathrm{S}$ to $18.7^{\circ} \mathrm{S}$ ), May-June 1993.

${ }^{\mathrm{f}}$ Glider relative geostrophic transport, includes Indispensable Strait, Jul-Oct 2005.

${ }^{\mathrm{g}}$ Glider absolute transport above $600 \mathrm{~m}$, includes Indispensable Strait, Jul-Oct 2005.

${ }^{\text {h }}$ Secalis 3 cruise, includes Indispensable Strait, Jul 2005.

${ }^{\mathrm{i}}$ Flusec cruise, value cited is unadjusted geostrophic transport relative to $2000 \mathrm{db}$ and is the same whether or not Indispensable Strait transport is included (F. Gasparin 2012, personal communication).

${ }^{\mathrm{j}}$ Record-length means calculated from the datasets described in section 2, integrated over the track shown in Fig. 1 from $20^{\circ}$ to $10^{\circ} \mathrm{S}$.

degree latitude per month. However, the number and spacing of XBT probes launched during a ship's voyage, and the dates of the voyages, were highly irregular (Fig. 1b). While it might have been ideal to consider the data as a set of individual transects, about $15 \%$ of the profiles could not be identified as belonging to a particular transect, and other transects were broken or incomplete, so we simply organized them according to their date and latitude along the defined track (Fig. 1); within the track width the longitude was ignored. For each XBT temperature value, a mean $T-S$ relation from the Commonwealth Scientific and Industrial Research Organisation Atlas of Regional Seas (CARS) gridded compilation (Dunn and Ridgway 2002; http://www.cmar. csiro.au/cars) was used to associate a salinity. The resulting temperatures and salinities were interpolated to regular 5-m depth intervals, then at each depth gridded alongtrack in $(y, t)$ using a Gaussian mapping procedure to a $0.5^{\circ}$ latitude by 3 -month grid, using mapping scales $0.75^{\circ}$ latitude and 3 months, and accepting profiles within twice these scales from each grid point. This filled all gaps, at the cost of interpolating across several gaps of up to 9.5 months on parts of the track in the early years of the record (Fig. 1b). Dynamic height relative to $400 \mathrm{~m}$ was found from the gridded temperature and salinity, and cross-track geostrophic currents and transports estimated by centered differencing.

Second, the Argo Atlas (Roemmich and Gilson 2009) provides gridded temperature and salinity profiles to $2000 \mathrm{db}$ on a global $1^{\circ}$ by $1^{\circ}$ monthly grid. The Argo 
Atlas temperatures and salinities were sampled along the XBT track at $1^{\circ}$ latitude intervals to produce a time series comparable to the XBT data from 2004 through 2011. Dynamic heights, cross-track, and zonal geostrophic currents were found relative to $2000 \mathrm{db}$ or the deepest common level. Note that while the Argo depths are reported in pressure units (db), the other datasets used here report depths in meters; as the difference is about $1 \%$, when making direct comparisons we ignore this difference.

Third, weekly Archiving, Validation, and Interpretation of Satellite Oceanographic (AVISO) satellite altimetric sea surface height (SSH) anomaly data on a roughly $13^{\circ}$ grid from August 1992 through 2011 (Ducet et al. 2000) was sampled along the same track and used to find surface geostrophic velocity anomalies.

For all three datasets, anomalies were found as differences from the average annual cycle over the record length of each time series, then filtered with a 7-month triangle. This filter has a half-power point of about 8 months and passes more than $80 \%$ of the variability with time scales longer than 13 months; its output is here referred to as "interannual."

Significance of correlations cited here was estimated according to the method of Davis (1976; also see Kessler et al. 1996, section 6a). Integral time scales for interannual correlations among these time series were about 10 months, so time series with short overlapping periods had about 15 degrees of freedom, while those with long overlaps had up to 40. All correlations cited here are significant at the $95 \%$ level or higher.

We also use the CARS gridded long-term mean temperature and salinity fields for additional comparison, calculating dynamic height and geostrophic flow along the XBT track as for Argo. CARS incorporates all available profile data, including all the XBT data in Fig. 1, Argo data through about 2008, as well as other profiles in the region [including the World Ocean Circulation Experiment (WOCE) P11S profiles discussed below in section 4]. As such, CARS is the most authoritative gridded profile data product in this region. Its gridding algorithm is less smooth than the Argo Atlas and is especially suited to the western South Pacific because particular attention has been paid to not gridding across the many islands and bathymetric ridges (Dunn and Ridgway 2002).

\section{c. Uncertainty of XBT-estimated transport}

We show below that individual sections across the SEC (such as a single oceanographic cruise or XBT section) can be unrepresentative because of high eddy activity in the region (Qiu et al. 2009). To some degree, eddy errors are reduced in the transport measures used here because eastward and westward transient velocities tend to cancel as an eddy passes through the section, but the aliasing can still be substantial. The AVISO weekly estimate of surface geostrophic velocity provides a means to test the sampling uncertainty of the core time series studied here: interannual variability of the SEC seen in XBT data. This testing is discussed in the appendix; the result is that for the average 6-week separation between XBT cruises, the signal/noise ratio for interannual variability is about 5.9, suggesting that the XBT sampling captures most of the interannual variations; this was borne out by visual inspection of the subsamples used for testing, which showed that all produced a time series very similar to the full weekly record. A 12-week sample separation produced signal/noise ratio of about 2.1; the 12 individual subsampled time series all showed the broad features of the ENSO cycle but with visually larger spread.

\section{Results}

\section{a. Mean transports and representativeness of shallow transport anomalies}

Although here we are concerned with anomalies, especially since we consider data sources with very different sampling characteristics, total transport values are relevant to show what is and is not sampled by $400-\mathrm{m}$ XBT profiles, to compare perpendicular transport across the slanted XBT track (Fig. 1) to meridional transport sections, and to evaluate the magnitudes of ENSO and other anomalies relative to mean transport values.

Strong currents in the Coral Sea can extend well below the thermocline (Sokolov and Rintoul 2000; Maes et al. 2007; Ganachaud et al. 2008; Gourdeau et al. 2008; Gasparin et al. 2011), so a useful geostrophic description of the mean flow must be made relative to a deep reference level.

Mean speed perpendicular to the XBT track from Argo Atlas data relative to $2000 \mathrm{db}$ (Fig. 2c) shows the two well-known westward jets of the Coral Sea. The relatively broad North Vanuatu Jet (NVJ) is found between about $10^{\circ}$ and $15^{\circ} \mathrm{S}$, mostly above the thermocline as has previously been described (Gourdeau et al. 2008). Its maximum speed relative to $2000 \mathrm{db}$ is about $8.5 \mathrm{~cm} \mathrm{~s}^{-1}$ at $14^{\circ} \mathrm{S}, 100-\mathrm{m}$ depth. The narrower and deeper North Caledonian Jet (NCJ) (Maes et al. 2007; Gourdeau et al. 2008; Ganachaud et al. 2008; Gasparin et al. 2011) is centered between $17^{\circ}$ and $18^{\circ} \mathrm{S}$ (immediately north of the New Caledonian reef), with its maximum speed near $300 \mathrm{~m}$ and strongly reversed shear above. A snapshot of absolute velocity from lowered ADCP and glider data has shown that the NCJ can 
maintain speeds to as much as $15 \mathrm{~cm} \mathrm{~s}^{-1}$ to depths of $1500 \mathrm{~m}$ or below (Gourdeau et al. 2008; and the other studies referenced above also show a narrow band of high speed extending to $1000 \mathrm{~m}$ or below), so the $2000 \mathrm{db}$ reference available from Argo data may not be sufficient, but the NCJ subsurface maximum is similar to the earlier studies. Although the core and deep extension of the NCJ are found just at the reef edge at $17^{\circ}-18^{\circ} \mathrm{S}$, the shallower southward bulge to $20^{\circ} \mathrm{S}$ is probably flow coming through the 600-m-deep Grand Passage (Gourdeau et al. 2008). As this joins the NCJ and feeds the Coral Sea, we include it in the transport measured here.

Between the two westward jets, the shallow eastward Coral Sea Countercurrent (CSCC) (Qiu et al. 2009) is centered at $16^{\circ} \mathrm{S}$, and south of New Caledonia the littlestudied westward, mostly subsurface, South Caledonian Jet does not enter the Coral Sea but is part of the southern branch of the SEC (Fig. 2c).

Argo cross-track currents relative to $400 \mathrm{db}$ (Fig. 2b) are suitable for comparison with the XBT data (Fig. 2a). Both relative-to-400-db fields are quite similar, with Argo currents slightly smoother and weaker but all the structures at the same latitudes and approximately the same depths (cf. Figs. 2a and b). These differences could be due to the coarser averaging used to construct the Argo Atlas, or to low-frequency variations sampled in different decades. Relative to $400 \mathrm{db}$ the mean Argo NVJ has about half of the speed of the 2000-db reference level, but the NCJ at $17^{\circ}-18^{\circ} \mathrm{S}$ has almost disappeared, reduced from more than $5 \mathrm{~cm} \mathrm{~s}^{-1}$ to about $0.5 \mathrm{~cm} \mathrm{~s}^{-1}$ near $300 \mathrm{~m}$ (Fig. 2b), similar to the XBT currents. The westward maximum near $19^{\circ} \mathrm{S}$ in both Argo and XBT fields is probably flow exiting the Grand Passage [Gourdeau et al. (2008), note the Grand Passage indicated in Fig. 2]. The near absence of the NCJ relative to the shallow reference level is consistent with the $300-\mathrm{m}$ speed maximum found from the deeper Argo data and previous studies.

Mean NCJ transport relative to $2000 \mathrm{db}$ from the Argo Atlas is about $-11 \mathrm{~Sv}\left(\mathrm{~Sv} \equiv 10^{6} \mathrm{~m}^{3} \mathrm{~s}^{-1}\right)$, and NVJ transport is about $-16 \mathrm{~Sv}$. By contrast, transports relative to the $400-\mathrm{m}$ XBT reference level are $-0.5 \mathrm{~Sv}$ for the NCJ and $-7 \mathrm{~Sv}$ for the NVJ, for both Argo and XBT data. Thus relative-to-400-db transports omit most of the mean transport of the NCJ, and about half of the mean transport of the NVJ. Total transports integrated from $20^{\circ} \mathrm{S}$ to $10^{\circ} \mathrm{S}$ are -6 and $-7 \mathrm{~Sv}$ relative to $400 \mathrm{db}$ from the Argo and XBT data, respectively, and $-27 \mathrm{~Sv}$ from the Argo data relative to $2000 \mathrm{db}$ (Table 1). An analogous calculation from the CARS gridded fields gives similar values for 400-db transport and $-30 \mathrm{~Sv}$ relative to $2000 \mathrm{db}$.

The usefulness of perpendicular velocities across the slanted section can be checked using a meridional section at $160^{\circ} \mathrm{E}$ from the Argo Atlas. Relative to $2000 \mathrm{db}$ the NCJ, CSCC, and NVJ on the purely meridional section have an almost identical structure to that on the track-sampled field, with slightly stronger peak velocities but the same total $\left(20^{\circ}-10^{\circ} \mathrm{S}\right)$ zonal transport of $-27 \mathrm{~Sv}$ (Fig. 2d). This correspondence is expected since the vector current from Argo is nearly zonal so the crosstrack velocity component gives the same integral. A similar calculation at $160^{\circ} \mathrm{E}$ from the CARS climatology relative to $2000 \mathrm{~m}$ gives a transport of about $-30 \mathrm{~Sv}$, again the same as its value along the XBT track.

The Argo Atlas provides a further check on the representativeness of transport variability relative to $400 \mathrm{db}$. Argo time series of interannual SEC transport relative to 400 and $1000 \mathrm{db}$ are highly correlated with that relative to $2000 \mathrm{db}$ ( $r=0.93$ and 0.98 , respectively). The rms of interannual transport relative to $1000 \mathrm{db}$ is about $46 \%$ larger than to $400 \mathrm{db}$ and that relative to $2000 \mathrm{db}$ is about $54 \%$ larger; that is, most of the interannual signal occurs in the upper $400 \mathrm{~m}$, and most of the remainder occurs above $1000 \mathrm{db}$. The high correlations and upperconcentrated variance are consistent with the idea that ENSO variability occurs primarily through thermocline depth fluctuations and suggest that the XBT 400-m transport gives a good representation of the temporal variance pattern, though not its magnitude.

\section{b. Interannual transport anomalies}

Unfortunately the XBT and Argo time series do not overlap, so no direct comparison can be made (Fig. 3). However, cross-track surface geostrophic currents derived from AVISO satellite SSH span both these in situ data time series and can be used to bridge them.

It is clear from Fig. 3 that ENSO dominates interannual transport variability; all the estimates of the SEC are well-correlated with the Southern Oscillation index (SOI) with a few-month lag consistent with Rossby wave propagation from the midbasin focus of ENSO wind variability (see next section). The 15-yr XBT transport correlates with the SOI at 0.85 with a 4 -month lag, the 8-yr Argo transport at 0.68 with a 2-month lag, and the 19-yr AVISO surface cross-track current (averaged over the XBT track from $20^{\circ}$ to $10^{\circ} \mathrm{S}$ ) at 0.76 with a 3 -month lag. This apparent change in lag times between the XBT and Argo transports is not due to difference in the datasets or their sampling but to the different periods they cover. This was evaluated by finding correlations between AVISO current on the XBT track and the SOI in a running 5-yr window; this showed an abrupt shift in the best lag time from about five months during 1996-2000 to about two months during 2002-08 (where the lag value is cited at the center points of the 5 -yr windows). However, Fig. 3 suggests that the 5-month lag found in the late $1990 \mathrm{~s}$ is largely due to the SOI-AVISO 


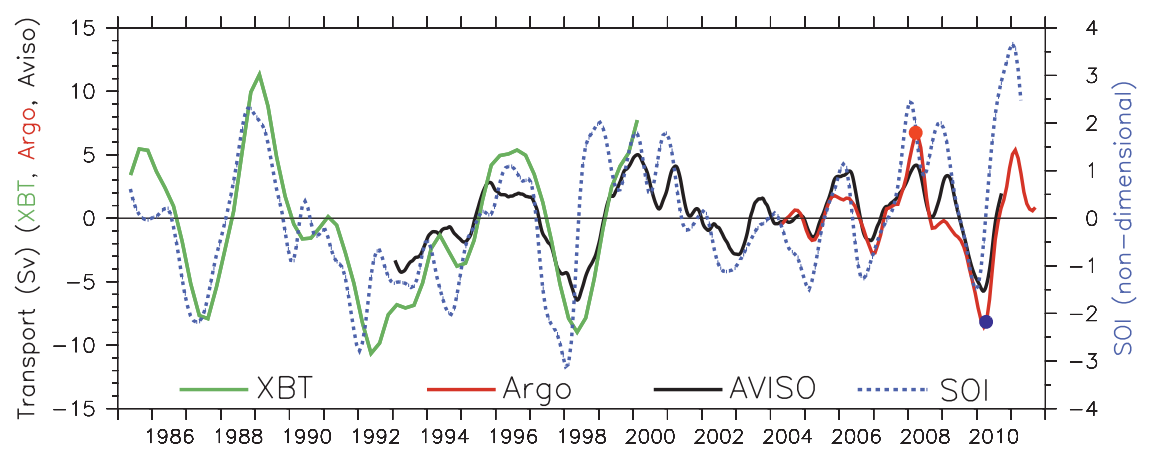

FIG. 3. Time series of interannual transport anomalies relative to $400 \mathrm{~m}$ (Sv) on the XBT track between $20^{\circ}$ and $10^{\circ} \mathrm{S}$ from the XBT data (green), Argo data (red), and AVISO surface speed interpreted as transport using a depth scale of $113 \mathrm{~m}$ (black, see text). The SOI is overlaid (blue dotted line, scale at right). Large red and blue dots on the Argo time series show times of the El Niño (February 2008) and La Niña (February 2010) example sections in Fig. 4.

discrepancy during the large-amplitude anomalies of the 1997-98 El Niño. The Rossby model developed in section $3 \mathrm{c}$ below allows extending the comparison back to the 1980s; this confirms both the short lags of the 2000s and the long lag time of the late 1990s, but also indicates that pre-1996 lags were consistently about 3 months. That suggests a real difference in ENSO character between the 1980s and 1990s versus the 2000s. The shorter recent lag times could reflect the change from the strong, east-Pacific-centered El Niños during the earlier period sampled by XBT and AVISO data, to the late 2000s sampled by Argo when central Pacific "Modoki" El Niños (Ashok et al. 2007) produced wind anomalies farther west (e.g., McPhaden et al. 2011).

The ENSO signal in cross-track velocity is clearly seen in examples of SEC anomalies on the track during an El Niño and a La Niña. The two examples shown in Fig. 4 (February 2008 for La Niña and February 2010 for El Niño, indicated by the red and blue dots in Fig. 3) were chosen as typical of strong events; their anomalies correspond to the pattern and magnitude of interannual variability calculated over the entire record. Anomalies of zonal flow were strongest at the surface and toward the north end of the section (Fig. 4). Near-surface NVJ speeds increased by about $50 \%$ following the El Niño of 2009-10 and decreased about the same amount following the La Niña of 2007-08, while changes of the NCJ were much smaller (Fig. 4). The weakening of interannual variance with depth corresponds to that seen in a time series from glider sampling across the mouth of the Solomon Sea (Davis et al. 2012). Westward transport relative to $1000 \mathrm{db}$ across the $20^{\circ}-10^{\circ} \mathrm{S}$ section was -23 Sv during climatological February (Fig. 4a), slightly weaker than the record-length mean. During La Niña in February 2008 transport relative to $1000 \mathrm{db}$ fell to $-14 \mathrm{~Sv}$, and during El Niño in February 2010 rose to $-35 \mathrm{~Sv}$
(Figs. 4b,c). Similar anomalies were seen during the other strong ENSO events, both in XBT and Argo data.

Since ENSO anomalies are surface intensified, it is not surprising that AVISO surface geostrophic velocities are well correlated with transport anomalies: the correlation of interannual AVISO speeds (averaged along the XBT line from $20^{\circ}$ to $10^{\circ} \mathrm{S}$ ) with XBT transport was 0.96 and with Argo transport was 0.90, as is obvious from Fig. 3. Regressing XBT and Argo transports against AVISO surface speeds (integrated over the 1334-km track length) gives a best-fit slope of $113 \mathrm{~m}$, which is the depth over which vertically uniform AVISO speeds would best approximate measured 0-400-m transport anomalies (or equivalently it is the vertical exponential decay scale of AVISO velocity to produce the measured transport). Analogous fits to Argo-only transports relative to deeper levels increase the slope by a factor of about 1.4 for 0/1000- or 1.5 for 0/2000-db transport, for depth scales of 158 or $170 \mathrm{~m}$, respectively. These values can be used to interpret interannual AVISO surface geostrophic speed anomalies, integrated along the track and multiplied by the depth scale, as a transport anomaly proxy.

\section{c. A simple Rossby wave model}

The simplest representation of low-frequency winddriven dynamics is the linear, reduced-gravity long Rossby wave model that has been frequently used to study tropical ocean variability (Meyers 1979; Kessler 1990; Chen and Qiu 2004; Kessler and Gourdeau 2007). While omitting many possible complexities: eddies, island or bottom effects, vertical wave propagation, and wave-mean flow interaction, the simple Rossby model is the first-order guess at the wind driven response, and can thereby illuminate the causes of the high correlation of SEC transport variability with ENSO as described above. Since transport across the XBT track would be 


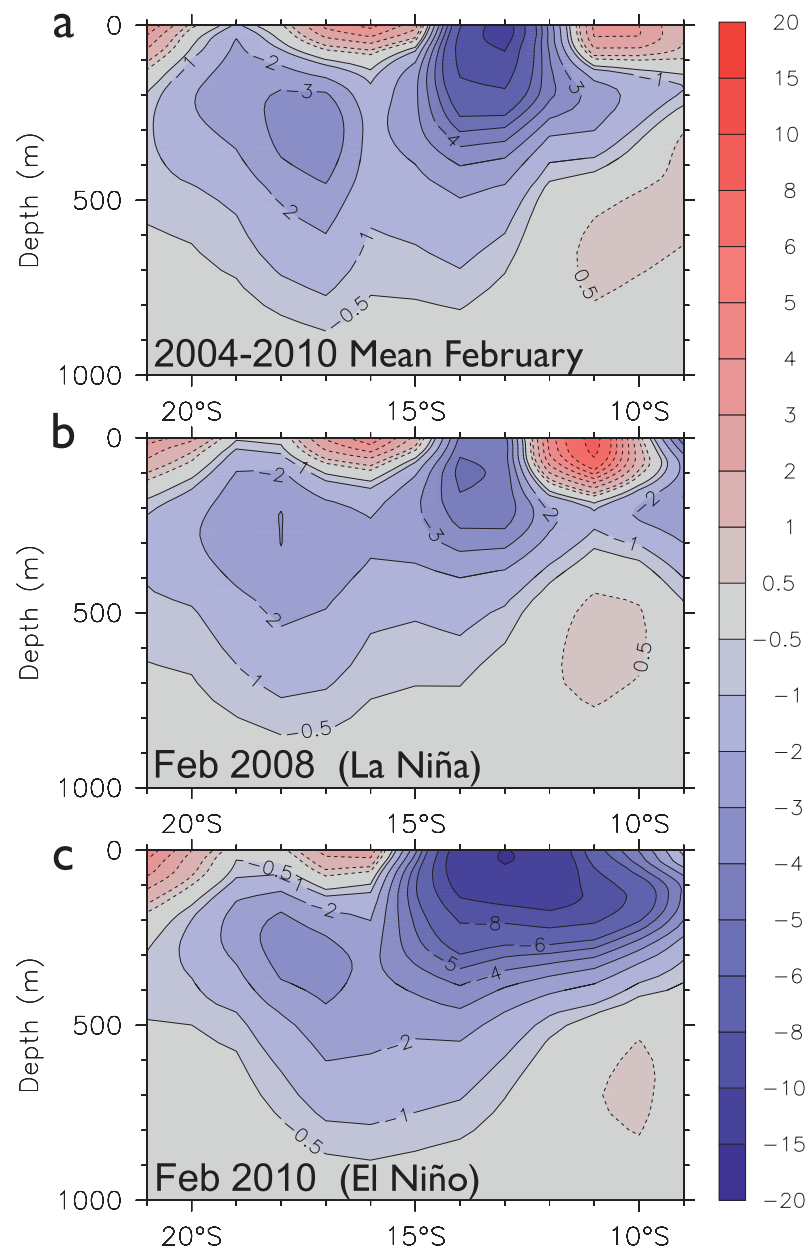

FIG. 4. Examples of cross-track currents relative to $1000 \mathrm{db}$ $\left(\mathrm{cm} \mathrm{s}^{-1}\right)$ from the Argo Atlas during (a) climatological mean February, (b) La Niña, and (c) El Niño conditions: negative values (blue) cross the track to the west. Dates of (b) and (c) are indicated by the dots in Fig. 3 .

the means by which the Coral Sea feels the effect of winds over the east-central Pacific, the ability to interpret this transport as due to Rossby propagation would be a clue to Coral Sea interannual variability.

The model is

$$
\frac{\partial h}{\partial t}+c_{r} \frac{\partial h}{\partial x}+R h=-\operatorname{curl}\left(\frac{\tau}{f \rho}\right)
$$

where $h$ is the pycnocline depth anomaly (positive down). The long Rossby speed is $c_{r}=-\beta c^{2} / f^{2}$, ( $c$ is the internal long gravity wave speed, $f$ is the Coriolis parameter, and $\beta$ its meridional derivative), $R$ is a damping time scale, and $\tau$ is the wind stress (data sources are given below). The two parameters to be chosen are $c$ and $R$, which we take to be $c=2.8 \mathrm{~m} \mathrm{~s}^{-1}$ and $R=(24 \text { months })^{-1}$. In this case, the results are only weakly sensitive to these choices because
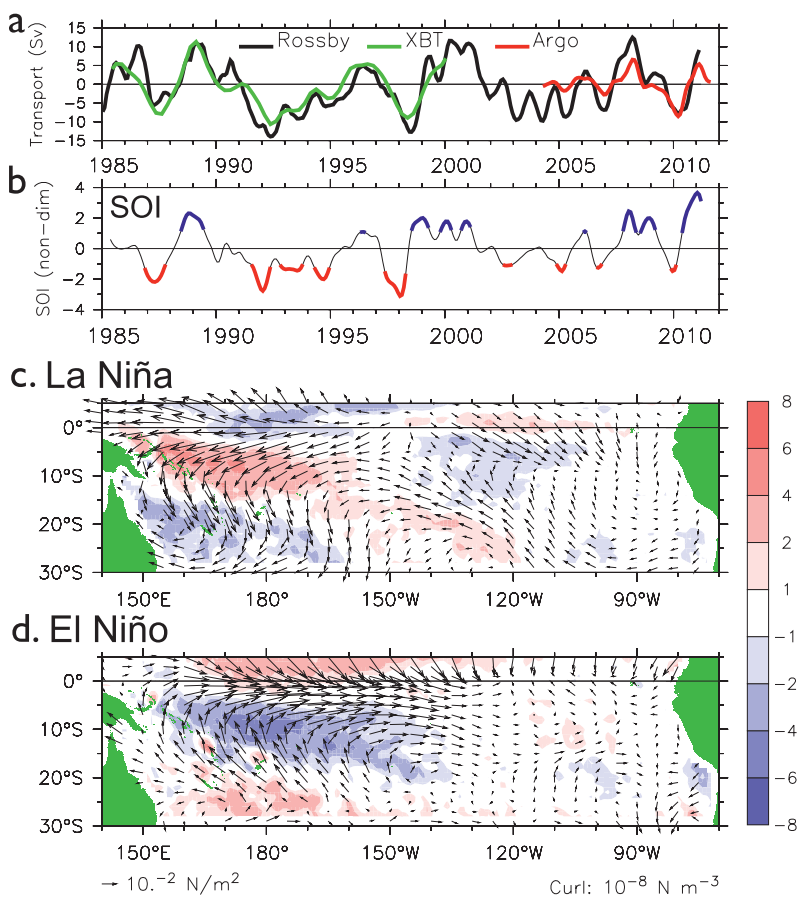

FIG. 5. (a) Time series of transport anomalies (Sv) from the Rossby model (black), XBT data (green), and Argo (red): XBT and Argo time series are the same as in Fig. 3. (b) Southern Oscillation index, where red and blue shading indicates El Niño (SOI less than -1 ) and La Niña (SOI greater than +1 ), respectively. (c) Mean wind stress vectors and curl (colors, scale at right) averaged over the La Niña periods shown in (b): units given at bottom. (d) As in (c) but for El Niño periods.

the largest interannual forcing is in the western half of the basin (Fig. 5, bottom panels), so differences in propagation have little time to manifest themselves. We ignore signals that might emanate from the eastern boundary (Kessler 1990; Minobe and Takeuchi 1995; Vega et al. 2003; Fu and Qiu 2002), so solutions represent purely the linear response to interior-ocean wind stress curl.

The model was forced with a sequence of interannually filtered monthly wind stresses: from January 1981 to July 1991 with ship-derived winds from the Center for OceanAtmospheric Predictions Studies at Florida State University (Bourassa et al. 2005), then until July 1999 with scatterometer winds from European Remote Sensing Satellite (ERS)-1 and -2, then until November 2009 with Quick Scatterometer (QuikSCAT) winds, then until February 2011 with Cross-Calibrated Multiplatform (CCMP) satellite winds (Atlas et al. 2011). We ignored the effects of islands: stresses $\tau$ were linearly interpolated in longitude across all the islands east of Australia-New Guinea, then we did not consider any effects of island blocking (Island Rule, Firing et al. 1999).

Geostrophic zonal transports analogous to XBT and Argo estimates (Fig. 3) were found from the solution 
$h(x, y, t)$ of $(1)$, using $U=-\left(c^{2} / f\right) d h / d y$, then similarly integrated from $20^{\circ}$ to $10^{\circ} \mathrm{S}$.

The Rossby model transport time series is well correlated with the 15-yr XBT transport $(r=0.85)$ and with 400-db-reference-level Argo transport ( $r=0.77$, Fig. 5a). The magnitude of wind-predicted transport anomalies is somewhat larger than the observed (Fig. 5a, where the rms of transport anomalies is $5.2 \mathrm{~Sv}$ from XBT data, 3.0 Sv from Argo data, and 6.3 Sv from the Rossby model solution). As with the XBT, Argo, and AVISO time series, the Rossby solution has a strong ENSO signal, with a lag relation to the SOI similar to what was seen for the XBT and Argo transport (section 3b; Figs. 5a,b).

The genesis of the ENSO transport signals expressed in the Rossby model can be seen by comparing average wind stress and curl over peaks of the ENSO cycle: defining La Niña as those times when the SOI was greater than +1 and $\mathrm{El}$ Niño when it was less than -1 (blue and red highlighting in Fig. 5b). Because ENSO appears to have changed character after 1999 (as we noted above regarding the different lags of XBT and Argo transport with the SOI), this definition is flawed by producing an "El Niño" average primarily from the period before 1999 and a "La Niña" average mostly from the time after. In effect, the method does not distinguish between interannual and longer time-scale variations.

La Niña periods have easterly wind anomalies spanning the equator to about $10^{\circ} \mathrm{S}$ west of about $150^{\circ} \mathrm{W}$, then northwesterlies south of about $12^{\circ} \mathrm{S}$. Downwelling curl (red shades in Figs. 5c,d) north of $15^{\circ} \mathrm{S}$ deepens the thermocline there and to the west, while upwelling curl from $15^{\circ}$ to $25^{\circ} \mathrm{S}$ shoals it; the result is an anomalous tilt down toward the equator that weakens the usual upward slope of the equatorward side of the gyre, with consequent weakening of the SEC. Similar but opposite-sign anomalies occur during El Niño, with the entire pattern shifted a few degrees south (Fig. 5d; Harrison and Vecchi 1999). The curl patterns south of $20^{\circ} \mathrm{S}$ suggest that a second reversal of anomalies occurs at $25^{\circ}-30^{\circ} \mathrm{S}$, implying anomalous westward flow during La Niña and eastward during El Niño (Figs. 5c,d); thus La Niña can be seen as shifting the subtropical gyre to the south and El Niño to the north (Wyrtki and Wenzel 1984).

\section{An example of eddy aliasing?}

Published synoptic estimates of geostrophic transport entering the Coral Sea (Table 1) were coincidentally taken at times when the ENSO cycle was nearly neutral and thus do not provide a useful test of the SEC response to ENSO. Scully-Power (1973) found $-30 \mathrm{~Sv}$ relative to $1500 \mathrm{~m}$ from a cruise at $162^{\circ} \mathrm{E}$ in August-September 1970, while Gourdeau et al. (2008) found $-28 \mathrm{~Sv}$

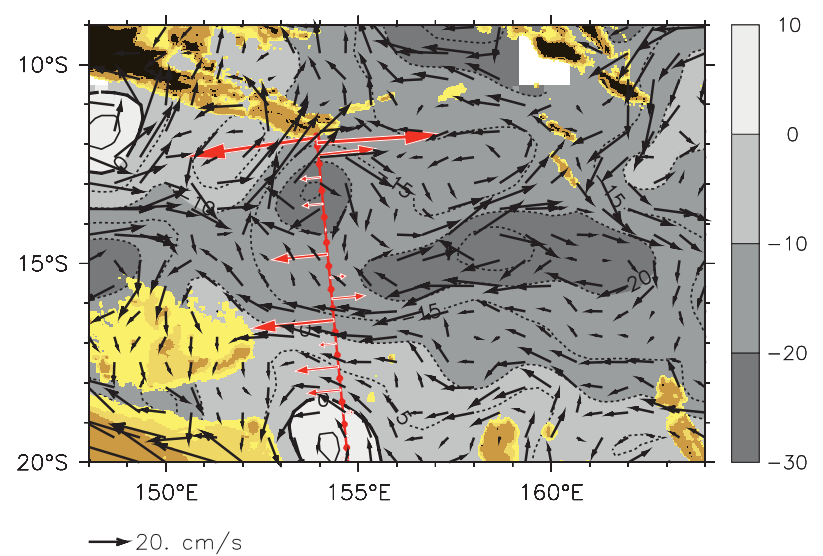

FIG. 6. AVISO sea level anomalies (gray shading, $\mathrm{cm}$, scale at right) and surface geostrophic velocity (black vectors, scale at lower left) during the WOCE P11S cruise in June-July 1993. The P11S ship track is shown in red with dots for CTD stations, roughly along $154.5^{\circ} \mathrm{E}$. Red vectors along the P11S track show the crosstrack surface geostrophic speed relative to $2000 \mathrm{db}$ (or the deepest common level) from P11S data (same vector scale). Note that, while the northernmost P11S vector is strongly westward, it is a shallow $(278 \mathrm{~m})$ station pair only $10 \mathrm{~km}$ apart. Yellow-brown shading shows bottom bathymetry, with shading levels at 0,100 , 500 and $1000 \mathrm{~m}$.

relative to $2000 \mathrm{db}$ in August-October 2005 (Table 1). Geostrophic transport relative to $2000 \mathrm{db}$ measured during the Flusec cruise in August 2008 was -24 Sv (F. Gasparin 2012, personal communication). These values are probably not significantly different from the mean transport from the Argo Atlas and CARS climatological means ( -27 and $-30 \mathrm{~Sv}$, respectively). Other estimates cited in Table 1 were either not at the entrance to the Coral Sea or were adjusted by an inverse or other model and cannot be directly compared.

\section{a. SEC transport during the WOCE P11S cruise}

The WOCE P11S cruise crossed the western Coral Sea roughly along $154.5^{\circ} \mathrm{E}$ in June-July 1993 (Fig. 6). Sokolov and Rintoul (2000) defined the P11S SEC as station pairs with westward vertically integrated geostrophic transport (thus from about $13^{\circ}$ to $19^{\circ} \mathrm{S}$ ); this transport was found to be $-54 \mathrm{~Sv}$ relative to $2000 \mathrm{db}$. The P11S cruise took place along a section west of the other published estimates (Fig. 6), measuring the SEC entering the Gulf of Papua, not the Coral Sea itself, and is thus not straightforwardly comparable to the other values. Yet, SEC transport across the P11S section should be smaller than across the XBT track because it is known that at least several sverdrups of the flow entering the Coral Sea turns north into the Solomon Sea before crossing the P11S section (Scully-Power 1973; Melet et al. 2010; Gasparin et al. 2012; Davis et al. 2012). 
As sources of mass to the P11S section other than across the XBT track are small or nonexistent, a transport smaller than at the entrance to the Coral Sea seems inescapable. For example, Argo Atlas mean SEC transport sampled on the $\mathrm{P} 11 \mathrm{~S}$ line was $-24 \mathrm{~Sv}$ relative to $2000 \mathrm{db}$, about $3 \mathrm{~Sv}$ smaller than the Argo value on the XBT line, while a comparable calculation from CARS also gave $-22 \mathrm{~Sv}$ on the P11S line, $8 \mathrm{~Sv}$ smaller than on the XBT track. Thus the $-54 \mathrm{~Sv}$ transport measured on P11S was much larger than expected from the climatological mean circulation. (For a direct comparison, the entire 8-yr range of monthly Argo Atlas 0/2000-db SEC transport values sampled on the P11S line was from -16 to -37 Sv.) The P11S cruise took place shortly after the relatively weak El Niño of 1993, and the AVISO proxy from section $3 b$ above suggests that ENSOrelated transport anomalies would have been a westward SEC transport increase of about $-3 \mathrm{~Sv}$ during this period: not nearly enough to account for the large P11S value.

\section{b. SEC anomalies below $1000 \mathrm{db}$ during P11S}

One source of the discrepancy was very large transport due to isopycnal slopes extending down to at least $2000 \mathrm{db}$ (about $2.25^{\circ} \mathrm{C}$ potential temperature) during P11S. The deep P11S isopycnal slopes are consistent over at least $400 \mathrm{~km}$ (eight CTD stations) and are thus unlikely to reflect internal wave aliasing. This deep signal produced a large fraction of the $-54 \mathrm{~Sv}$ P11S transport, with transport relative to $1000 \mathrm{db}$ only about $55 \%$ of the $0 / 2000 \mathrm{db}$ total. By contrast, mean Argo Atlas $0 / 1000-d b$ transport on this line was about $70 \%$ of its $0 / 2000 \mathrm{db}$ total (similar to the fraction found from Argo on the XBT line), and the eight years of monthly average Argo Atlas data in this region had no examples of meridional isotherm slopes at these depths as large as those measured on P11S (indeed, not half as large). Without a hypothesis to understand this deep signal, we leave the problem to future study and ask if the stillvery-large upper transport anomalies in P11S [-30 Sv relative to $1000 \mathrm{db}$, nearly double the mean transports from Argo ( $-17 \mathrm{~Sv}$ ) or from CARS ( $-16 \mathrm{~Sv})$ ] can be explained in terms of short-term eddy aliasing seen in AVISO weekly SSH.

\section{c. AVISO surface currents on the P11S transect}

AVISO SSH anomalies were interpolated to the P11S station locations and cross-track geostrophic speed computed, then averaged over the station pairs where SEC transport was westward during the P11S cruise (approximately $19^{\circ}$ to $13^{\circ} \mathrm{S}$ ). These section-mean speeds were decomposed into annual and interannual time series as was done for the profile datasets, and a high-passed

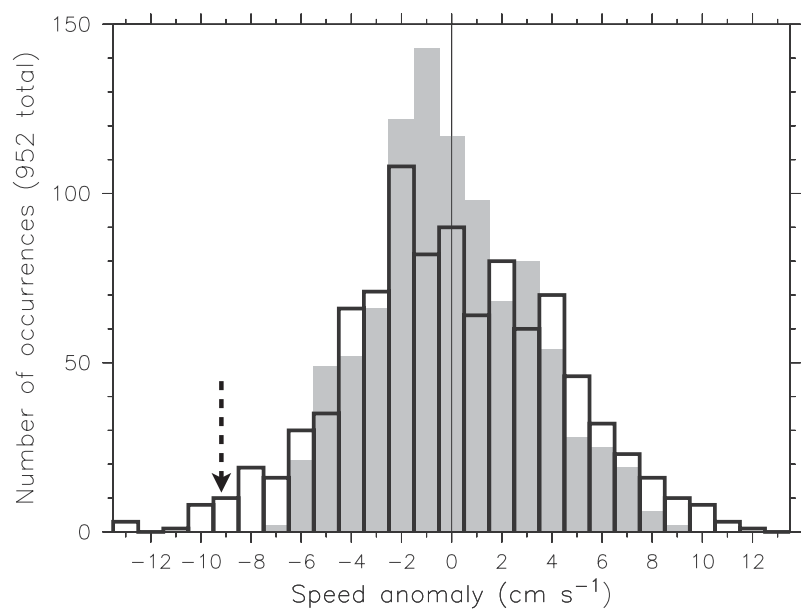

FIG. 7. Histograms of AVISO weekly speed anomalies averaged along the XBT track (gray shading) and P11S track (outlines) during October 1992 through December 2010. Each bar shows the number of occurrences in each $1 \mathrm{~cm} \mathrm{~s}^{-1}$ range (of a total 952 weekly occurrences for each time series). The vertical dashed arrow shows the AVISO value $\left(-9.1 \mathrm{~cm} \mathrm{~s}^{-1}\right)$ during the week that the P11S cruise crossed the Coral Sea (30 Jun 1993).

time series was formed by subtracting the annual and interannual values from the unfiltered weekly data.

While the annual cycle and interannual rms of AVISO P11S speeds were similar to those found from an analogous calculation on the XBT track, the high-passed rms on the P11S track was about $70 \%$ larger than on the XBT track (thus the high-passed signal on P11S was larger than the interannual). The range of section-mean speeds during the 18 years of AVISO was correspondingly larger on P11S, and the histogram of (total, unfiltered) AVISO speeds on P11S was more spread (Fig. 7).

The larger high-frequency AVISO variance in the western Coral Sea is consistent with eddy generation approximately along $16^{\circ} \mathrm{S}$ west of Vanuatu, where Qiu et al. (2009) described 70-day eddy signals in SSH and SST and diagnosed them as due to barotropic instability between the SEC branches and the CSCC (Fig. 3c). Inspection of weekly maps shows that much of this variability is due to westward-moving mesoscale eddies with typical zonal scales of $200-400 \mathrm{~km}$ and anomalous surface geostrophic velocities of $20 \mathrm{~cm} \mathrm{~s}^{-1}$ or more (e.g., Fig. 6). Zonal lag correlations of high-passed AVISO SSH indicate that these eddies move west with speeds decreasing from about $-14 \mathrm{~cm} \mathrm{~s}^{-1}$ at $14^{\circ} \mathrm{S}$ to $-10 \mathrm{~cm} \mathrm{~s}^{-1}$ at $20^{\circ} \mathrm{S}$, that is, with somewhat smaller meridional speed gradient than would be expected from linear Rossby wave propagation (Chelton et al. 2011; Maharaj et al. 2009). At these speeds and scales, an individual eddy would affect a section line for up to $\sim 30$ days. However, most of the time such an eddy will produce oppositely directed velocity anomalies on its flanks that result in 
only small transport anomalies when integrated over a section as considered here.

In the westward SEC where vertically integrated transport is negative, P11S surface currents averaged $-12.9 \mathrm{~cm} \mathrm{~s}^{-1}$, while comparable AVISO section-mean speed anomalies in late June to early July 1993 were $-9.1 \mathrm{~cm} \mathrm{~s}^{-1}$. That is, about three-fourths of the shipmeasured surface velocity in the SEC region during the P11S cruise appears to have been transient. (Note that the AVISO SEC speed anomaly on P11S at this time had larger magnitude than $97 \%$ of its 952 weekly values between October 1993 and December 2010, emphasizing the exceptionally strong high-passed anomalies during the P11S cruise, Fig. 7). Using the ability to decompose AVISO into three frequency bands shows that of this $-9.1 \mathrm{~cm} \mathrm{~s}^{-1} 46 \%$ can be attributed to high-passed variability, 35\% to interannual (following the weak El Niño of 1993 ), and $19 \%$ to the phase of the annual cycle (June-July is near the westward climatological peak). We note that, if the cruise had been conducted two months earlier, AVISO anomalies along the P11S section would have had the opposite sign, underlining the significance of the short-term signals. A similarly shortterm augmentation of the background eastward flow along the coast of Papua New Guinea was also seen during P11S, suggesting a transiently amplified cyclonic circulation in the western Coral Sea at this time (Fig. 6).

\section{d. AVISO-based estimates of transport anomalies}

One guess at the anomaly vertical scale would be the equivalent depth found on the XBT track by interannual regression between AVISO velocity and Argo transport reported above (158 $\mathrm{m}$ for $0 / 1000-\mathrm{db}$ transport). Since the annual and interannual AVISO variance is similar along the two tracks and since both signals are known to be dominated by thermocline-depth fluctuations in this region (Holbrook and Bindoff 1997, 1999; Kessler and Gourdeau 2007), this measure is reasonable for those lowfrequency time scales. If that is the case, the $-4.8 \mathrm{~cm} \mathrm{~s}^{-1}$ AVISO annual-plus-interannual signal during the P11S period would represent about a $-4.5 \mathrm{~Sv}$ westward transport anomaly. That is about one-third of the difference between the $-30 \mathrm{~Sv}$ P11S transport relative to $1000 \mathrm{db}$ and the climatological mean values from Argo and CARS of -16 and $-17 \mathrm{~Sv}$, respectively.

If the eddy vertical scale is the same $158 \mathrm{~m}$, they would contribute another $-4.3 \mathrm{~Sv}$ westward transport anomaly. However, there is no reason to assume that the eddy depth scale be the same as that for lower frequencies, and indeed most studies have suggested that both baroclinic (Roemmich and Gilson 2001) and barotropic (Qiu et al. 2009) eddies in the western tropical Pacific extend through the thermocline much below $158 \mathrm{~m}$. An eddy vertical scale of $475 \mathrm{~m}$ would fully account for the remaining difference (about $-12 \mathrm{~Sv}$ ) between P11S and the climatological mean estimates of SEC transport.

We conclude that the WOCE P11S cruise took place during a period of westward transport anomalies over the SEC region; the annual cycle, interannual and eddy signals all contributed, with the eddy contribution the most important, amounting to perhaps one-third of the measured transport.

This has an important implication for interpreting the redistribution of incoming flow from the SEC. Sokolov and Rintoul (2000) noted that the -54 Sv SEC transport across P11S implied that about $29 \mathrm{~Sv}$ of the arriving westward flow turns south into the East Australian Current (with about $25 \mathrm{~Sv}$ going into the Solomon Sea). That would contradict estimates from climatology $(\mathrm{Qu}$ and Lindstrom 2002; Ridgway and Dunn 2003), from the repeated high-resolution XBT sections out of Brisbane at $27^{\circ} \mathrm{S}$ (Roemmich et al. 2005), and from earlier cruise data (Scully-Power 1973). However, if the circulation at any instant is strongly perturbed by eddies (as well as ENSO), then deductions based on an individual cruise may not be a useful guide to the background circulation.

\section{Conclusions}

Historical section data extending back to 1985 are used to estimate the interannual variability of transport entering the Coral Sea between New Caledonia and the Solomon Islands. Typical magnitudes of this variability that can be estimated from XBT profiles are $\pm 5-8 \mathrm{~Sv}$ in the $0 / 400-\mathrm{m}$ layer relative to $400 \mathrm{~m}$. While those values are comparable to the mean transport relative to $400 \mathrm{~m}$ (Table 1), in fact interannual variability in this region occurs largely through thermocline depth fluctuations and is thus reasonably well sampled by $400-\mathrm{m}$ XBT profiles, increasing by at most a factor of $\sim 1.5$ in the 0/2000-db layer that is sampled by Argo floats. Mean transport entering the Coral Sea can be estimated either from the eight years of Argo data or from the CARS long-term climatology ( -22 or $-24 \mathrm{~Sv}$, respectively, relative to $1000 \mathrm{db}$ ), and close to $-30 \mathrm{~Sv}$ relative to $2000 \mathrm{db}$ (Table 1 ).

Westward transport entering the Coral Sea increases a few months after an El Niño event and decreases following a La Niña. A linear, reduced-gravity Rossby model reproduces the observed interannual transport variability well and shows that much of the ENSO transport anomalies are due to coherent wind changes over the western half of the basin, extending south to at least $20^{\circ} \mathrm{S}$. The SEC fluctuations are consistent with ENSO transport anomalies measured across the mouth of the Solomon Sea from satellite altimetry by Melet et al. (2010) and from glider data by Davis et al. (2012), 
supporting the hypothesis that at least much of the interannual anomalies of the NVJ turn equatorward directly into the Solomon Sea. Interannual transport fluctuations are about $50 \%$ larger than annual-cycle transport variability; both tend to be largest at the equatorial end of the section with much smaller variability in the North Caledonian Jet near $18^{\circ} \mathrm{S}$.

Vigorous westward-propagating mesoscale eddies produce strong intraseasonal current fluctuations on zonal scales of $200-400 \mathrm{~km}$, but often these average out over a long section as considered here. Occasionally these eddies can be transiently aligned to yield substantial aliasing on an individual section, perhaps to onethird or more of the measured transport. We believe this to be the case for the highly anomalous transports measured along the WOCE P11S section in the western Coral Sea (Sokolov and Rintoul 2000). While interannual and seasonal variability have comparable magnitude in the west as at the eastern entrance to the sea, eddy signals estimated from AVISO SSH are about $70 \%$ larger in the west, making transport estimates there more challenging.

Since interannual transport is well correlated with AVISO surface geostrophic currents and its variability is surface intensified, a simple index based on AVISO currents can be used as a proxy for upper-ocean SEC transport anomalies. However, given the few degrees of freedom for interannual variability in the 23 total years of subsurface data available here, the proxy should be considered reliable for the phase, but not necessarily the amplitude, of interannual variations. A further shortcoming is that we are unable to separate variability owing to ENSO, which might have a random element to its occurrences in a fairly short record, from trends or decadal variability. This is particularly the case for the apparent regime shift following the 1997/98 El Niño.

Acknowledgments. This paper was possible because of the data collection, compilation, and quality control efforts of several national and international programs. The quality-controlled XBT profiles were produced and made available by the Coriolis Data Centre (http://www. coriolis.eu.org). The Argo profiling float data were collected and made available by the International Argo Program and the national programs that contribute to it (http://www.argo.ucsd.edu). The AVISO altimeter products were produced by Ssalto/Duacs and distributed by AVISO, with support from CNES (http://www.aviso. oceanobs.com/duacs/). Gridded wind products were made available by the Center for Ocean-Atmosphere Prediction studies at Florida State University (http:// coaps.fsu.edu/RVSMDC/FSUFluxes/), for ERS by the Centre ERS d'Archivage et de Traitement (http://cersat. ifremer.fr/), and for QuikScat by Remote Sensing Systems (http://www.remss.com). The authors acknowledge $\mathrm{K}$. Ridgway and an anonymous reviewer, whose comments greatly helped to focus our ideas. This work also benefited from discussions with Florent Gasparin, Lionel Gourdeau, Alexandre Ganachaud and, as always, Dennis Moore. This work is cofunded by the Agence Nationale de la Recherche (Project ANR-09-BLAN-0233-01) and by INSU/LEFE/IDAO project Solwara; it is a contribution to the SPICE International programs (http://www. solomonseaoceanography.org).

\section{APPENDIX}

\section{AVISO Sampling Test}

The AVISO weekly estimate of surface geostrophic flow provides a means to test the sampling uncertainty of the core time series studied here: interannual variability of the SEC seen in XBT data. The merchant ships in the VOS program typically launched an XBT probe each change of watch or as part of routine weather observations, thus every 4-6 h; this means that most of the profiles during an individual voyage were $1^{\circ}-1.5^{\circ}$ latitude apart (Fig. 1b). Since not all profiles could be assigned to a particular voyage, the average spacing between voyages is not well defined, but was densely spaced during 1989-93 (an average of more than one section per month), sparser with sections 1-1.5 months apart in the later years, but much spottier coverage in the first few years (Fig. 1b).

To test the representativeness of this sampling, AVISO weekly surface geostrophic cross-track velocities averaged over $20^{\circ}-10^{\circ} \mathrm{S}$ were subsampled every six weeks, this procedure being repeated six times starting from sequential weeks, yielding six subsamples. Each of the resulting time series was processed exactly as described above: the average annual cycle was found and removed, and the result smoothed with a 7-month triangle filter. Differences among the six realizations of interannual variability were compared with that from the full weekly record. The rms of the full time series was $2.2 \mathrm{~cm} \mathrm{~s}^{-1}$, which we will consider the "signal" for this purpose. Rms differences from this signal among the six realizations ranged from 0.32 to $0.42 \mathrm{~cm} \mathrm{~s}^{-1}$, with an overall rms of $0.38 \mathrm{~cm} \mathrm{~s}^{-1}$, which is an estimate of the noise owing to the 6-week sampling separation. The signal/noise ratio is thus about 5.9, suggesting that the XBT sampling captured most of the interannual variations; this was borne out by visual inspection of the six subsamples, which showed that all produced a time series very similar to the full weekly record. A similar experiment with 12-week sample separation produced rms differences about $1 \mathrm{~cm} \mathrm{~s}^{-1}$ and signal/noise ratio of 
about 2.1; the 12 individual subsampled time series all showed the broad features of the ENSO cycle but with larger spread.

Figure 7 also shows the probability of aliasing of sectionmean surface current in a single realization: On the XBT track $50 \%$ of the transient values had magnitudes smaller than $2.0 \mathrm{~cm} \mathrm{~s}^{-1}$, while $90 \%$ were smaller than $5.3 \mathrm{~cm} \mathrm{~s}^{-1}$; on the P11S track the corresponding $50 \%$ and $90 \%$ magnitudes were greater, about 2.9 and $7.1 \mathrm{~cm} \mathrm{~s}^{-1}$, respectively.

\section{REFERENCES}

Alory, G., and T. Delcroix, 2002: Interannual sea level changes and associated mass transports in the tropical Pacific from TOPEX/Poseidon data and linear model results (1964-1999). J. Geophys. Res., 107, 3153, doi:10.1029/2001JC001067.

Andrews, J. C., and S. Clegg, 1989: Coral Sea circulation and transport deduced from modal information models. Deep-Sea Res., 36, 957-974.

Ashok, K., S. K. Behara, S. A. Rao, H. Weng, and T. Yamagata, 2007: El Niño Modoki and its possible teleconnection. J. Geophys. Res., 112, C11007, doi:10.1029/2006JC003798.

Atlas, R., R. N. Hoffman, J. Ardizzone, S. M. Leidner, J. C. Jusem, D. K. Smith, and D. Gombos, 2011: A cross-calibrated multiplatform ocean surface wind velocity product for meteorological and oceanographic applications. Bull. Amer. Meteor. Soc., 92, 157-174.

Bourassa, M. A., R. Romero, S. R. Smith, and J. J. O'Brien, 2005: A new FSU winds climatology. J. Climate, 18, 3692-3704.

Chelton, D. B., M. G. Schlax, and R. M. Samelson, 2011: Global observations of nonlinear mesoscale eddies. Prog. Oceanogr., 91, 167-216

Chen, S., and B. Qiu, 2004: Seasonal variability of the South Equatorial Countercurrent. J. Geophys. Res., 109, C08003, doi:10.1029/2003JC002243.

Cravatte, S., A. Ganachaud, Q.-P. Duong, W. S. Kessler, G. Eldin, and P. Dutrieux, 2011: Observed circulation in the Solomon Sea from SADCP data. Prog. Oceanogr., 88 (1-4), 116-130.

Davis, R. E., 1976: Predictability of sea surface temperature and sea level pressure anomalies over the North Pacific Ocean. J. Phys. Oceanogr., 6, 249-266.

— W. S. Kessler, and J. T. Sherman, 2012: Gliders measure western boundary current transport from the South Pacific to the equator. J. Phys. Oceanogr., 42, 2001-2013.

Delcroix, T., and C. Henin, 1989: Mechanisms of subsurface thermal structure and sea surface thermohaline variabilities in the southwestern tropical Pacific during 1975-85. J. Mar. Res., 47, 777-812.

Ducet, N., P.-Y. LeTraon, and G. Reverdin, 2000: Global highresolution mapping of ocean circulation from TOPEX/Poseidon and ERS-1 and -2. J. Geophys. Res., 105 (C8), 19 477-19 498.

Dunn, J. R., and K. R. Ridgway, 2002: Mapping ocean properties in regions of complex topography. Deep-Sea Res. I, 49, 591-604.

Fine, R. A., R. Lukas, F. M. Bingham, M. J. Warner, and R. H. Gammon, 1994: The western equatorial Pacific: A water mass crossroads. J. Geophys. Res., 99 (C12), 25 063-25 080.

Firing, E., B. Qiu, and W. Miao, 1999: Time-dependent island rule and its application to the time-varying North Hawaiian Ridge Current. J. Phys. Oceanogr., 29, 2671-2688.

Fu, L.-L., and B. Qiu, 2002: Low-frequency variability of the North Pacific Ocean: The roles of boundary- and wind-driven baroclinic Rossby waves. J. Geophys. Res., 107, 3220, doi:10.1029/ 2001JC001131.

Ganachaud, A., L. Gourdeau, and W. S. Kessler, 2008: Bifurcation of the subtropical south equatorial current against New Caledonia in December 2004 from a hydrographic inverse box model. J. Phys. Oceanogr., 38, 2072-2084.

Gasparin, F., A. Ganachaud, and C. Maes, 2011: A western boundary current east of New Caledonia: Observed characteristics. Deep-Sea Res. I, 58, 956-969.

,,$-- \ldots$, F. Marin, and G. Eldin, 2012: Oceanic transports through the Solomon Sea: The bend of the New Guinea Coastal Undercurrent. Geophys. Res. Lett., 39, L15608, doi:10.1029/2012GL052575.

Gourdeau, L., W. S. Kessler, R. E. Davis, J. Sherman, C. Maes, and E. Kesternare, 2008: Zonal jets entering the Coral Sea. J. Phys. Oceanogr., 38, 715-725.

Gouriou, Y., and T. Delcroix, 2002: Seasonal and ENSO variations of sea surface salinity and temperature in the South Pacific Convergence Zone during 1976-2000. J. Geophys. Res., 107, 8011, doi:10.1029/2001JC000830.

Grenier, M., S. Cravatte, B. Blanke, C. Menkes, A. Koch-Larrouy, F. Durand, A. Melet, and C. Jeandel, 2011: From the western boundary currents to the Pacific Equatorial Undercurrent: Modeled pathways and water mass evolutions. J. Geophys. Res., 116, C12044, doi:10.1029/2011JC007477.

Harrison, D. E., and G. A. Vecchi, 1999: On the termination of E Niño. Geophys. Res. Lett., 26, 1593-1596.

Holbrook, N. J., and N. L. Bindoff, 1997: Interannual and decadal temperature variability in the southwest Pacific Ocean between 1955 and 1988. J. Climate, 10, 1035-1049.

— and _ 1999: Seasonal temperature variability in the upper southwest Pacific Ocean. J. Phys. Oceanogr., 29, 366-381.

Johnson, G. C., and M. J. McPhaden, 1999: Interior pycnocline flow from the subtropical to the equatorial Pacific Ocean. J. Phys. Oceanogr., 29, 3073-3089.

Kessler, W. S., 1990: Observations of long Rossby waves in the northern tropical Pacific. J. Geophys. Res., 95 (C4), 5183-5217. , and L. Gourdeau, 2007: The annual cycle of circulation in the southwest subtropical Pacific, analyzed in an ocean GCM. J. Phys. Oceanogr., 37, 1610-1627.

— M. C. Spillane, M. J. McPhaden, and D. E. Harrison, 1996: Scales of variability in the equatorial Pacific inferred from the tropical atmosphere-ocean buoy array. J. Climate, 9, 2999-3024

Maes, C., L. Gourdeau, X. Couvelard, and A. Ganachaud, 2007: What are the origins of the Antarctic Intermediate Waters transported by the North Caledonian Jet? Geophys. Res. Lett., 34, L21608, doi:10.1029/2007GL031546.

Maharaj, A. M., N. J. Holbrook, and P. Cipollini, 2009: Multiple westward-propagating signals in South Pacific sea level anomalies. J. Geophys. Res., 114, C12016, doi:10.1029/ 2008JC004799.

McPhaden, M. J., T. Lee, and D. McClurg, 2011: El Niño and its relationship to changing background conditions in the tropical Pacific Ocean. Geophys. Res. Lett., 38, L15709, doi:10.1029/ 2011GL048275.

Melet, A., L. Gourdeau, and J. Verron, 2010: Variability in Solomon Sea circulation derived from altimeter sea level data. Ocean Dyn., 60, 883-900.

Meyers, G., 1979: The annual Rossby waves in the tropical North Pacific Ocean. J. Phys. Oceanogr., 9, 663-674.

-, and J.-R. Donguy, 1980: An XBT network with merchant ships. Trop. Ocean-Atmos. Newsl., 2, 6-7. 
Minobe, S., and K. Takeuchi, 1995: Annual period equatorial waves in the Pacific Ocean. J. Geophys. Res., 100 (C9), 18 379-18 392.

Qiu, B., W. S. Kessler, and S. Chen, 2009: Source of the 70-day mesoscale eddy variability in the Coral Sea and North Fiji Basin. J. Phys. Oceanogr., 39, 404-420.

Qu, T., and E. J. Lindstrom, 2002: A climatological interpretation of the circulation in the western South Pacific. J. Phys. Oceanogr., 32, 2492-2508.

Ridgway, K. R., and J. S. Godfrey, 1994: Mass and heat budgets in the East Australian Current-A direct approach. J. Geophys. Res., 99 (C2), 3231-3248.

— , and J. R. Dunn, 2003: Mesoscale structure of the mean East Australian Current system and its relationship with topography. Prog. Oceanogr., 56, 189-222.

Roemmich, D., and J. Gilson, 2001: Eddy transport of heat and thermocline waters in the North Pacific: A key to interannual/ decadal climate variability? J. Phys. Oceanogr., 31, 675-687.

__ and _-, 2009: The 2004-2008 mean and annual cycle of temperature, salinity, and steric height in the global ocean from the Argo program. Prog. Oceanogr., 82, 81-100.

$\_, \ldots$, J. Willis, P. Sutton, and K. Ridgway, 2005: Closing the time-varying mass and heat budgets for large ocean areas: The Tasman Box. J. Climate, 18, 2330-2343.
Scully-Power, P. D., 1973: Coral Sea flow budgets during winter. Aust. J. Mar. Freshwater Res., 24, 203-215.

Sokolov, S., and S. R. Rintoul, 2000: Circulation and water masses of the southwest Pacific: WOCE section P11, Papua New Guinea to Tasmania. J. Mar. Res., 58, 223-268.

Taft, B. A., and W. S. Kessler, 1991: Variations of zonal currents in the central tropical Pacific during 1970 to 1987: Sea level and dynamic height measurements. J. Geophys. Res., 96, 12 599-12 618.

Tsuchiya, M., R. Lukas, R. A. Fine, E. Firing, and E. Lindstrom 1989: Source waters of the Pacific equatorial undercurrent. Prog. Oceanogr., 23, 101-147.

Vega, A., Y. du-Penhoat, B. Dewitte, and O. Pizarro, 2003: Equatorial forcing of interannual Rossby waves in the eastern South Pacific. Geophys. Res. Lett., 30, 1197, doi:10.1029/2002GL015886.

Wyrtki, K., 1962: Geopotential topographies and associated circulation in the western South Pacific. Aust. J. Mar. Freshwater Res., 13, 89-105. , and J. Wenzel, 1984: Possible gyre-gyre interaction in the Pacific Ocean. Nature, 309, 538-540.

Zilberman, N. V., D. H. Roemmich, and S. T. Gille, 2013: The mean and the time variability of the shallow meridional overturning circulation in the tropical South Pacific Ocean. J. Climate, in press. 